Moncecious ( $A G$ ) Andromonœcious $\left(a^{1} G\right)$ Gyncocious $(A g)$ Hermaphrodite $\left(a^{1} g\right)$
$P$ between $0 \cdot 3$ and $0 \cdot 2$. The flt is good.

A number of $F_{3}$ populations raised from selected $F_{2}$ plants representing the different classes supported the hypothesis of two-factor inheritance.

(2) Monoscious $(A A G G) \times$ Andromonosious $\left(a^{1} a^{1} G G\right) . \quad F_{1}$ plants $\left(A a^{1} G G\right)$ were monœcious. In the $F_{2}$, monœeious and andromonœeious types segregated in the ratio of $3: 1$ as under :

$\begin{array}{lcc} & \text { Observed } & \text { Expected }(3: 1) \\ \text { Monœcious }(A G) & 23 \cdot 0 & 22 \cdot 5 \\ \text { Andromonœcious }\left(a^{1} G\right) & 7 \cdot 0 & 7 \cdot 5\end{array}$

(3) Hermaphrodite $\left(a^{1} a^{1} g g\right) \times$ Andromonocious $\left(a^{1} a^{1} G G\right) . \quad F_{1}$ plants $\left(a^{1} a^{1} G g\right)$ were andromonœecious. In the $F_{2}$, andromonocious and hermaphrodite segregated in the ratio of $3: 1$ as stated below :

\section{Andromonœcious $\left(a^{1} G\right)$ Hermaphrodite $\left(a^{1} g\right)$}

Observed

Expected

The two-factor inheritance obtained in the above crosses was further confirmed by the following test crosses :

(1) Monœeious $(A A G G) \times$ Hermaphrodite $\left(a^{1} a^{1} g g\right)$ $\times$ Monoecious $(A A G G)$. The progeny ( $A A G G$, $\left.A A G g, A a^{1} G G, A a^{1} G g\right)$ was all moncecious.

(2) Monœcious $(A A G G) \times$ Hermaphrodite $\left(a^{1} a^{1} g g\right)$ $\times$ Hermaphrodite $\left(a^{1} a^{1} g g\right)$. The progeny segregated in the ratio of 1 moncecious $\left(A a^{1} G g\right): 1$ andromonœcious $\left(a^{1} a^{1} G g\right)$ : 1 gynœeious $\left(A a^{1} g g\right)$ : 1 hermaphrodite $\left(a^{1} a^{1} g g\right)$.

(3) (i) Gynœecious $(A A g g) \times$ Monœcious $(A A G G)$. The progeny was all monœcious. (ii) Gynœcious $\left(A a^{1} g g\right) \times$ Moncecious $(A A G G)$. The progeny was all monœcious.

(4) (i) Gynœeious $(A A g g) \times$ Andromonœeious $\left(a^{1} a^{1} G G\right)$. The progeny was all monœcious. (ii) Gynœeious $\left(A a^{1} g g\right) \times$ Andromonœecious $\left(a^{1} a^{1} G G\right)$. The progeny consisted of monœcious and andromonceious in the ratio of $1: 1$.

(5) (i) Gynœcious (AAgg) $\times$ Hermaphrodite $\left(a^{1} a^{1} g g\right)$. The progeny consisted of all gynœcious plants. (ii) Gynocious $\left(A a^{1} g g\right) \times$ Hermaphrodite $\left(a^{1} a^{1} g g\right)$. The progeny consisted of equal proportions of gynœeious and hermaphrodite plants.

It is clear from the foregoing results that two pairs of factors are involved in the inheritance of sex forms in the various crosses. There is, however, an interesting difference between the phenotypic segregation observed by Poole and Grimball and that obtained by us in the $F_{2}$ population of the cross between monœecious and hermaphrodite. While the former obtained 9 monœcious : 3 andromonœcious : 3 gynomonœeious : 1 hermaphrodite in the $F_{2}$, our population showed 9 monœcious : 3 andromonœcious : 3 gynœcious : 1 hermaphrodite; the gynomonœcious form in their material was replaced by gynœeious in our $F_{2}$ population. Furthermore, unlike the gynomonocious type of Poole and Grimball, the gynœecious type was stable and did not show any environmental variations. It would appear, therefore, that the gynœcious form is a definite genotype different from that of the gynomonœcious.

On the basis of these results it seems reasonable to suppose that two gene loci each with a multiple allelomorphic series $\left(A-a^{1}-a\right.$ and $\left.G-g^{1}-g\right)$ are concerned in the inheritance of the sex forms in Luffa. Thus, the various possible sex forms may be tentatively designated as: Monœecious $A G$, Andromonœecious $a^{1} G$, Andrœcious $a G$, Gynomonœecious $A g^{1}$, Gynœcious $A g$, Hermaphrodite $a g, a^{1} g^{1}, a^{1} g$ and $a g^{1}$.

The above tentative genic hypothesis is in accord with the results obtained in the various crosses studied by us. It also provides an explanation for the different phenotypic segregations in the $F_{2}$ of the cross between moncecious and hermaphrodite, observed in our material and that of Poole and Grimball. It is likely that the genotype of the hermaphrodite form used in crosses with monœecious by Poole and Grimball was of the constitution $a^{1} a^{1} g^{1} g^{1}$, in which case the $F_{2}$ segregation would give 9 monœcious $(A G), 3$ andromonœecious $\left(a^{1} G\right), 3$ gynomonœcious $\left(A g^{1}\right)$ and 1 hermaphrodite $\left(a^{1} g^{1}\right)$.

We have not so far come across andrœcious and gynomonœcious forms nor a dicecious species of Luffa; but it is possible that they may be found in the future when further investigations will be undertaken to confirm or modify the hypothesis proposed in this note.

We are indebted to Dr. N. Parthasarathy, geneticist, Indian Agricultural Research Institute, for reading through the manuscript and making some useful suggestions.

${ }^{2}$ Poole, O. F., and Grimball, P. C., J. Hered., 30, 21 (1939).

\section{PLANT VIRUS RESEARCH AT CAMBRIDGE}

By DR. KENNETH M. SMITH, F.R.S.

Plant Virus Research Unit, Molteno Institute, Cambridge

$\mathrm{O}^{\mathrm{N}}$ April 29, at an informal gathering in Cam. bridge, the new field laboratory of the Plant Virus Research Unit of the Agricultural Research Council was inaugurated, and demonstrations illustrating the principal researches carried out there were staged.

The ceremony also marked the twenty-first anniversary of the establishment at Cambridge of the Plant Virus Research Station, which has now become a research unit of the Agricultural Research Council. The project was started in 1927 under the auspices of the Ministry of Agriculture, and Dr. R. N. Salaman was appointed its first director with the present writer as senior research assistant. The scheme had a two-fold object: (1) to build up nucleus stocks of virus-free potatoes by propagating them in insect-proof glasshouses, and (2) to underta.ke research, in the first instance, into the virus diseases of the potato plant and their means of spread in the field. As time went on, however, the maintenance of the nucleus stocks of virus-free potatoes became a routine measure and the work was expanded to cover many aspects of plant virus research. Now, with the establishment of the research unit, the virus-free stocks are being handed into the care of the National Institute of Agricultural Botany, which will continue their propagation under glass while maintaining large stocks in strict isolation in the open.

As the importance of virus diseases of plants graduaily became recognized, so the work developed, and increasing interest in the activities of the station was taken by workers abroad. Since, with the 


\section{No. 4098 May 15, 1948}

exception of Rothamsted Experimental Station and a few centres in the United States, there existed no other laboratory where experience in so many aspects of plant virus study could be obtained, applications from foreign workers for this training became very frequent. Unfortunately, these activities had to be severely curtailed owing to the lack of laboratory accommodation. Nevertheless, it may be mentioned that students have come to take either research degrees or courses of instruction in plant virus work from Argentina, Australia, Belgium, Brazil, Canada, China, Czechoslovakia, Denmark, Gold Coast, India, New Zealand, Poland, Portugal, South Africa, Sweden and the United States, and visitors have come from all over the world.

In looking back over two decades, it becomes evident how, with increasing knowledge and new technical discoveries, the trend of virus research has changed. In the beginning, most of the emphasis was placed on the disease, and symptomatology was all-important, although the study of the relationships between the viruses and their insect vectors was already being undertaken. The isolation of tobacco mosaic virus by Stanley in 1935, however, was the key which opened the door to the study of the virus itself, quite apart from the disease it may cause. A brief review of some of the main contributions by the Cambridge workers illustrates this change of emphasis in virus research. For the first few years, attention was directed almost entirely towards potato virus diseases, and from this work three items of interest may be noted. The first of these was the identification of the insect vector of potato leaf-roll, which was later also found to carry another potato virus. This was the aphis, Myzus persica, and it was almost the first introduction to public notice of the aphis which, since that time, has become of paramount importance in the field of plant viruses and seems to be the most efficient vector of these agents in the world. It is now known to transmit more than twenty distinct viruses. The next addition to our knowledge of potato viruses was the discovery of the paracrinkle virus in potatoes of the variety King Edward; this is one of the unsolved puzzles of the virus world, since it is present in all plants of this potato variety, but no method is known by which it can spread in Nature. The case of paracrinkle is often quoted as evidence of the heterogenesis of viruses by those who hold this view. The third item was the analysis, for the first time, of a plant virus complex by differential methods of transmission, and the isolation of the two potato viruses now universally known as $X$ and $Y$.

In 1931 the virus of tomato spotted wilt was discovered for the first time in Europe; it was found in an ornamental plant sent to Cambridge from Cardiff. Before this it had not been seen outside Australia. Since then the distribution of the virus has become world-wide, and in Great Britein it is one of the major problems of the tomato grower with 'mixed houses'.

The viruses of tomato bushy stunt and tobacco necrosis, both described for the first time in Cambridge, have proved of great scientific interest. The virus of tomato bushy stunt, about which more is known than of most viruses, was the first to be isolated in a three-dimensional crystalline form, and this was accomplished by Bawden and Pirie, after the former had left Cambridge. Shortly after this the virus of tobacco necrosis was isolated as thin crystalline plates. About this time, also, the com- paratively new technique of plant virus serology was applied to the study of potato virus $X$.

In 1938 a new virus complex affecting the tobacco plant, known as 'rosette', was investigated, the chief point of interest being the apparent relationship between the two component viruses. This is suggested by the fact that, while both viruses are aphistransmitted if they are together in the plant, one of the two cannot be picked up by the insect if the other virus is not present.

During the period 1940-45, several new viruses have been described, those of Arabis, belladonna and lovage mosaic, tobacco broken ringspot, tomato black ring and of two new potato diseases, veinal necrosis and veinal yellows, which were found in some South American potatoes. Of these new viruses, those of Arabis mosaic and broken ringspot are of especial interest, since they appeared in plants,inside the experimental glasshouses with no apparent explanation of their origin.

During the last two years an extremely interesting and important new virus has been discovered and studied. Known as turnip yellow mosaic virus, it has been isolated in two different crystalline forms and, like other plant viruses studied so far, it is a nucleoprotein. In addition to the active virus, infected plants also contain a protein which is apparently the virus protein but lacks the nucleic acid. This protein has also been crystallized, and studies of the biological and biophysical properties of these two proteins are now in progress. The virus is also of interest in having an entirely new kind of insect vector, one with biting mouthparts, namely, a fleabeetle. This is the first record, both of transmission of a virus by this insect and of the insect transmission of a crystalline plant virus.

Electron microscope studies in conjunction with Dr. V. E. Cosslett of the Cavendish Laboratory, and with Dr. R. W. G. Wyckoff in the United States, have also been made [see p. 760 of this issue of Nature]. An interesting outcome of this work is that the structure of the crystals of tobacco necrosis virus and turnip yellow mosaic virus has been demon. strated by this means.

\section{A NEW MICROSCOPIC PRINCIPLE}

\author{
By Dr. D. GABOR \\ Research Laboratory, British Thomson-Houston Co., Ltd., \\ Rugby
}

$T$ is known that the spherical aberration of electron lenses sets a limit to the resolving power of electron microseopes at about $5 \mathrm{~A}$. Suggestions for the correction of objectives have been made; but these are difficult in themselves, and the prospects of improvement are further aggravated by the fact that the resolution limit is proportional to the fourth root of the spherical aberration. Thus an improvement of the resolution by one decimal would require a correc. tion of the objective to four decimals, a practically hopeless task.

The new microscopic principle described below offers a way around this difficulty, as it allows one to dispense altogether with electron objectives. Micrographs are obtained in a two-step process, by electronic analysis, followed by optical synthesis, as in Sir Lawrence Bragg's 'X-ray microscope'. But 